\title{
Kesehatan Hidung pada Lansia di Balai Pelayanan Sosial Lanjut Usia Terlantar Senja Cerah Manado
}

\author{
${ }^{1}$ Nadya N. Rompis \\ ${ }^{2}$ Olivia C. P. Pelealu, \\ ${ }^{2}$ Ora I. Palandeng
}
${ }^{1}$ Program Studi Pendidikan Dokter Fakultas Kedokteran Universitas Sam Ratulangi Manado
${ }^{2}$ Bagian/SMF Telinga Hidung Tenggorok-Bedah Kepala Leher Fakultas Kedokteran Universitas Sam Ratulangi - RSUP Prof. Dr. R. D. Kandou Manado
Email: nadyanatalia312@gmail.com

\begin{abstract}
In general, the importance of sense of smell gets little regards from people. This eventually leads to disorders and injuries which impair or terminate the physiological functions and capabilities of the nasal organs. Some of the commonly observed disorders are allergic rhinitis, nasal polyps, sinusitis, and epistaxis. One of the groups that requires health services the most is the senior citizens. This study was aimed to obtain an overview of nasal health among the elderly at Balai Pelayanan Sosial Lanjut Usia Terlantar Senja Cerah Manado. This was an observational descriptive study with a cross-sectional design. The results showed that there were 31 elderly people as subjects; $3 \%$ had masses in the left and right nasal cavities and 3\% had narrowing of left nasal cavity. Concha examination revealed that $3 \%$ of elderly had hyperemia and edema. Mucous examination showed that $3 \%$ of elderly had hyperemia. Secrete examination found 3\% of elderly had mucoid secretion. Moreover, septal deviation was found in $6 \%$ of elderly and post-nasal drip was found in 3\% of elderly. Conclusion: Most elderly at Balai Pelayanan Sosial Lanjut Usia Terlantar Senja Cerah Manado had good nasal health.

Keywords: nasal health, nasal examination
\end{abstract}

\begin{abstract}
Abstrak: Peran indra penghiduan kurang mendapat perhatian khusus dari masyarakat hingga pada akhirnya timbulnya gangguan atau cidera yang dapat menghilangkan kemampuan dan fungsi fisiologis dari organ hidung. Beberapa kelainan pada hidung yang sering ditemukan antara lain rinitis alergi, polip hidung, sinusitis, dan epistaksis. Salah satu kelompok masyarakat yang paling membutuhkan pelayanan kesehatan ialah penduduk lanjut usia. Penelitian ini bertujuan untuk mengetahui gambaran kesehatan hidung pada lansia di Balai Pelayanan Sosial Lanjut Usia Terlantar Senja Cerah Manado. Jenis penelitian ialah deskriptif observasional dengan desain potong lintang. Hasil penelitian mendapatkan 31 subyek lanjut usia. Hasil pemeriksaan menunjukkan dari 31 subyek tersebut, terdapat massa di kavum nasi kanan dan kiri sebesar 3\%, kavum nasi kiri sempit sebesar 3\%. Hasil pemeriksaan konka, ditemukan edema dan hiperemis sebesar 3\%. Pemeriksaan mukosa ditemukan keadaan hiperemis sebesar 3\%. Hasil pemeriksaan sekret, ditemukan sekret mukoid sebesar $3 \%$. Pemeriksaan septum ditemukan deviasi sebesar 6\%. Post nasal drip ditemukan sebesar 3\%. Simpulan: Sebagian besar lansia di Balai Pelayanan Sosial Lanjut Usia Terlantar Senja Cerah Manado menunjukkan kesehatan hidung yang terbilang baik.

Kata kunci: kesehatan hidung, pemeriksaan fisik hidung
\end{abstract}

Dalam Undang-Undang Kesehatan No. 23 tahun 1992, kesehatan secara lebih kom- pleks didefinisikan sebagai keadaan sejahtera dari badan, jiwa, dan sosial yang 
memungkinkan setiap orang hidup produktif secara sosial dan ekonomi. Dengan demikian, upaya kesehatan yang dilakukan mengarahkan masyarakat mencapai kesehatan yang cukup agar dapat hidup produktif. $^{1}$

Salah satu kelompok masyarakat yang paling membutuhkan pelayanan kesehatan ialah penduduk lanjut usia. Secara biologis, penduduk lanjut usia akan mengalami proses penuaan terus menerus ditandai menurunnya daya tahan fisik sehingga rentan terhadap serangan penyakit yang dapat menyebabkan kematian. ${ }^{2}$

Pada umumnya, peran penting dari indra penghiduan kurang mendapat perhatian khusus dari masyarakat sendiri, hingga akhirnya terjadi gangguan atau cidera yang dapat menghilangkan kemampuan dan fungsi fisiologis dari organ hidung. ${ }^{3}$ Beberapa kelainan pada hidung yang sering ditemukan antara lain rinitis alergi, polip hidung, sinusitis, dan epistaksis. Prevalensi rinitis alergi (RA) cukup bervariasi di setiap belahan dunia. Menurut Stewart et al. prevalensi rinitis alergi di seluruh dunia sekitar 10-40\%. ${ }^{4}$ Berdasarkan data epidemiologi RA di Indonesia, angka prevalensi bervariasi antara $1,14 \%-23,34 \%$ dan pada penelitian yang dilakukan di Semarang dengan menggunakan kuesioner ISAAC pada murid SMP berusia 13-14 tahun didapatkan sebesar $18,6 \%{ }^{5}$

Di Indonesia, prevalensi sinusitis termasuk tinggi. Hal ini berdasarkan data Depkes RI tahun 2003 yang menyebutkan bahwa penyakit tersebut berada pada urutan ke-25 dari 50 pola penyakit. ${ }^{6}$ Epistaksis diperkirakan terjadi pada $60 \%$ orang di seluruh dunia selama masa hidup mereka, dan sekitar $6 \%$ dari mereka dengan epistaksis datang ke pelayanan kesehatan. Prevalensi meningkat pada anak-anak kurang dari 10 tahun dan kemudian naik lagi setelah usia 35 tahun. ${ }^{7}$ Polip hidung merupakan masalah kesehatan global yang dapat memengaruhi kualitas hidup penderita baik segi pekerjaan, pendidikan, dan kegiatan aktivitas sehari-hari. Studi epidemiologi di Indonesia menunjukkan bahwa perbandingan pria dan wanita 2-3:1 dengan prevalensi $0,2 \%-4,3 \%$. Biasanya terjadi setelah usia 20 tahun dan banyak pada usia 40 tahun ke atas. ${ }^{8}$

Penelitian ini bertujuan untuk mendapatkan gambaran kesehatan hidung pada lansia di Balai Pelayanan Sosial Lanjut Usia Terlantar Senja Cerah Manado.

\section{METODE PENELITIAN}

Penelitian ini menggunakan metode deskriptif observasional dengan desain potong lintang. Subyek penelitian ialah lansia di BPSLUT Senja Cerah Manado.

\section{HASIL PENELITIAN}

Pada penelitian ini didapatkan subyek sebanyak 31 orang lansia yang terdiri dari laki-laki 11 orang (35\%) dan perempuan 20 orang $(65 \%)$ (Tabel 1).

Tabel 1. Karakteristik subyek penelitian berdasarkan jenis kelamin

\begin{tabular}{ccc}
\hline Jenis kelamin & n & $\begin{array}{c}\text { Persentase } \\
(\boldsymbol{\%})\end{array}$ \\
\hline Laki-Laki & 11 & 35 \\
Perempuan & 20 & 65 \\
Total & 31 & 100 \\
\hline
\end{tabular}

Tabel 2 menunjukkan distribusi pasien menurut usia. Persentase usia terbanyak ialah golongan lanjut usia tua yaitu 75-90 tahun sebanyak 17 orang (55\%), dan golongan lanjut usia yaitu 60-74 tahun sebanyak 14 orang $(45 \%)$. Tidak terdapat lansia golongan usia sangat tua yaitu $>90$ tahun.

Tabel 2. Karakteristik subyek penelitian berdasarkan usia

\begin{tabular}{ccc}
\hline $\begin{array}{c}\text { Usia } \\
\text { (tahun) }\end{array}$ & n & $\begin{array}{c}\text { Persentase } \\
(\boldsymbol{\%})\end{array}$ \\
\hline $60-74$ & 14 & 45 \\
$75-90$ & 17 & 55 \\
$>90$ & 0 & 0 \\
Total & 31 & 100 \\
\hline
\end{tabular}

Pemeriksaan status kesehatan hidung terdiri dari pemeriksaan kavum nasi, konka, mukosa, sekret, septum dan post nasal drips. Pada pemeriksaan kavum nasi 
didapatkan hasil kavum nasi kanan yang lapang berjumlah 30 orang $(97 \%)$ dan kavum nasi kiri yang lapang berjumlah 29 orang (94\%). Kavum nasi kanan dan kiri yang terdapat massa berjumlah satu orang (3\%), yaitu polip dengan grade 2 . Tidak ada kavum nasi kanan yang sempit sedangkan kavum nasi kiri yang sempit berjumlah satu orang (3\%)(Tabel 3).

Tabel 3. Keadaan kavum nasi subyek penelitian

\begin{tabular}{ccccc}
\hline Kavum & \multicolumn{2}{c}{ n } & \multicolumn{2}{c}{ Persentase (\%) } \\
\cline { 2 - 5 } nasi & Kanan & Kiri & Kanan & Kiri \\
\hline Lapang & 30 & 29 & 97 & 94 \\
Massa & 1 & 1 & 3 & 3 \\
Sempit & 0 & 1 & 0 & 3 \\
Total & 31 & 31 & 100 & 100 \\
\hline
\end{tabular}

Pemeriksaan konka mendapatkan hasil konka normal pada 30 orang (97\%), sedangkan konka edema disertai hiperemis pada satu orang (3\%) (Tabel 4). Pemeriksaan mukosa mendapatkan hasil mukosa normal pada 30 orang $(97 \%)$ sedangkan mukosa yang hiperemis pada satu orang (3\%) (Tabel 5).

Tabel 4. Keadaan konka subyek penelitian

\begin{tabular}{ccccc}
\hline Konka & \multicolumn{2}{c}{$\mathbf{c}$} & \multicolumn{2}{c}{$\begin{array}{c}\text { Persentase } \\
(\%)\end{array}$} \\
\cline { 2 - 5 } & Kanan & Kiri & Kanan & Kiri \\
\hline Normal & 30 & 30 & 97 & 97 \\
Edema & 0 & 0 & 0 & 0 \\
Hiperemis & 0 & 0 & 0 & 0 \\
Pucat & 0 & 0 & 0 & 0 \\
Atrofi & 0 & 0 & 0 & 0 \\
Edema + & 1 & 1 & 3 & 3 \\
hiperemis & & & & \\
Total & 31 & 31 & 100 & 100 \\
\hline
\end{tabular}

Tabel 5. Keadaan mukosa

\begin{tabular}{ccccc}
\hline \multirow{2}{*}{ Mukosa } & \multicolumn{2}{c}{ n } & \multicolumn{2}{c}{ Persentase (\%) } \\
\cline { 2 - 5 } & Kanan & Kiri & Kanan & Kiri \\
\hline Normal & 30 & 30 & 97 & 97 \\
Hiperemis & 1 & 1 & 3 & 3 \\
Livide & 0 & 0 & 0 & 0 \\
Total & 31 & 31 & 100 & 100 \\
\hline
\end{tabular}

Pada pemeriksaan sekret didapatkan hasil tidak ditemukan sekret dengan jumlah 30 orang $(97 \%)$, dan ditemukan sekret mukoid dengan jumlah satu orang (3\%) (Tabel 6). Pada pemeriksaan septum didapatkan hasil septum yang normal berjumlah 29 orang (94\%), sedangkan septum deviasi berjumlah dua orang (6\%) (Tabel 7).

Tabel 6. Keadaan secret subyek penelitian

\begin{tabular}{ccccc}
\hline \multirow{2}{*}{ Sekret } & \multicolumn{2}{c}{ n } & \multicolumn{2}{c}{$\begin{array}{c}\text { Persentase } \\
(\%)\end{array}$} \\
\cline { 2 - 5 } & Kanan & Kiri & Kanan & Kiri \\
\hline Tidak ada & 30 & 30 & 97 & 97 \\
Serous & 0 & 0 & 0 & 0 \\
Mukoid & 1 & 1 & 3 & 3 \\
Purulen & 0 & 0 & 0 & 0 \\
Total & 31 & 31 & 100 & 100 \\
\hline
\end{tabular}

Tabel 7. Keadaan septum subyek penelitian

\begin{tabular}{ccccc}
\hline \multirow{2}{*}{ Septum } & \multicolumn{2}{c}{$\mathbf{n}$} & \multicolumn{2}{c}{ Persentase (\%) } \\
\cline { 2 - 5 } & Kanan & Kiri & Kanan & Kiri \\
\hline Normal & 29 & 29 & 94 & 94 \\
Deviasi & 2 & 2 & 6 & 6 \\
Abses & 0 & 0 & 0 & 0 \\
Hematoma & 0 & 0 & 0 & 0 \\
Total & 31 & 31 & 100 & 100 \\
\hline
\end{tabular}

Pada pemeriksaan post nasal drip, didapatkan hasil post nasal drip negatif berjumlah 30 orang (97\%), dan post nasal drip positif berjumlah satu orang (3\%).

Tabel 8. Keadaan post nasal drip

\begin{tabular}{ccccc}
\hline \multirow{2}{*}{$\begin{array}{c}\text { Post } \\
\text { nasal } \\
\text { drip }\end{array}$} & \multicolumn{2}{c}{$\mathbf{n}$} & \multicolumn{2}{c}{ Persentase (\%) } \\
\cline { 2 - 5 } & Kanan & Kiri & Kanan & Kiri \\
\hline Ada & 1 & 1 & 3 & 3 \\
Tidak & 30 & 30 & 97 & 97 \\
Total & 31 & 31 & 100 & 100 \\
\hline
\end{tabular}

\section{BAHASAN}

Penelitian survei kesehatan hidung ini dilakukan pada lansia BPSLUT Senja Cerah Manado dengan desain potong lintang. Penelitian ini diikuti oleh 31 orang lansia yang bersedia menjadi subyek penelitian dengan persentase jenis kelamin perempuan lebih banyak (65\%).

Berdasarkan pemeriksaan kavum nasi 
didapatkan keadaan sebagian besar lapang pada subyek dengan persentase $94 \%$. Masalah pada kavum nasi yang ditemukan ialah massa pada satu orang (3\%). Masalah lainnya yang ditemukan ialah kavum nasi kiri sempit pada satu orang (3\%).

Polip nasi adalah massa lunak yang mengandung banyak cairan di dalam rongga hidung, berwarna putih keabuabuan, yang terjadi akibat inflamasi mukosa. Polip dapat timbul pada laki-laki maupun perempuan, dari usia anak-anak hingga usia lanjut. Salah satu teori predisposisi timbulnya polip nasi ialah adanya rinitis alergi atau penyakit atopi. Rinitis yang terjadi secara terus menerus dapat menyebabkan inflamasi kronik. ${ }^{9}$ Oleh karena itu, terjadinya polip nasi bisa dicurigai pada rinitis berulang di masa lampau. Kavum nasi dapat menjadi sempit salah satunya karena polip nasal. ${ }^{3}$

Pada pemeriksaan konka subyek penelitian, didapatkan keadaan normal sebanyak 30 orang $(97 \%)$, satu orang (3\%) mengalami edema dan hiperemis baik hidung kanan maupun kiri. Edema dan hiperemis pada konka dapat ditemukan pada keadaan inflamasi seperti rinitis. Hiperemis terjadi karena vasodilatasi kapiler-kapiler pada hidung ketika terjadi inflamasi. ${ }^{6}$ Peradangan persisten dalam sinus juga menyebabkan kerusakan pada silia berakibat selain penyumbatan pada hidung, silia yang sudah rusak menjadi media yang baik untuk pertumbuhan bakteri. ${ }^{10}$

Pada pemeriksaan mukosa subyek penelitian, didapatkan hasil sebagian besar normal (94\%). Keadaan abnormal yang didapatkan ialah mukosa mengalami hiperemis sebanyak satu orang (3\%). Perubahan mukosa ini sangat terkait dengan tandatanda rinitis, baik rinitis alergi atau rinitis vasomotor. Perubahan ini mirip dengan mekanisme yang terjadi pada konka. Rinitis akan berpengaruh pada pembuluh darah dalam hidung. Saat pembuluh darah dalam hidung vasodilatasi, maka akan terjadi peningkatan permeabilitas dari dinding pembuluh darah dan meningkatkan berbagai sekresi kelenjar-kelenjar di mukosa hidung. Perubahan ini juga dipengaruhi oleh emosi, posisi tubuh, keadaan psikologis yang tidak dirasakan sebagai gangguan pada individu tersebut. Oleh karena itu, kejadian hiperemis pada mukosa juga dapat terjadi tanpa adanya tanda rinitis ataupun penyakit lainnya pada hidung. ${ }^{11}$

Pemeriksaan sekret mendapatkan hanya satu subyek penelitian dengan sekret mukoid baik hidung kanan maupun hidung kiri. Sekret mukoid bersifat kental, ${ }^{11}$ dan berhubungan dengan mukosa. Pada pasien yang lebih tua, mukosa sering kering sehingga produksi lendir untuk melembabkan terlalu tebal. ${ }^{12}$

Hasil pemeriksaan septum mendapatkan $90 \%$ normal dan dua orang (6\%) mengalami deviasi. Septum deviasi adalah septum nasi yang tidak terletak lurus di tengah rongga hidung. Secara umum, beberapa etiologi dari septum deviasi ialah kongenital, genetik, trauma, infeksi, atau efek dari massa pada neoplasma kavum nasi. ${ }^{13}$ Septum deviasi bisa menjadi manifestasi dari trauma langsung akibat aktivitas fisik dan tidak menutup kemungkinan berhubungan dengan pekerjaan yang dilakukan para lansia pada waktu muda.

Pada pemeriksaan kesehatan hidung lansia di BPSLUT Senja Cerah Manado didapatkan satu orang (3\%) dengan post nasal drips pada hidung kanan, maupun hidung kiri. Post nasal drip adalah akumulasi lendir di belakang hidung dan memberikan sensasi lender menurun dari belakang hidung menuju tenggorokan. Post nasal drip dapat disebakan oleh sekresi yang berlebihan atau kental, dan gangguan dalam pembersihan lendir yang normal dari hidung dan tenggorokan. Frekuensi silia bergerak, serta waktu untuk pembersihan mukosiliar dalam epitel nasal, melambat dengan bertambahnya usia. Proses melambatnya transport mukosisiliar ini akan menyebabkan pembersihan alergen dan iritasi yang buruk, serta stasis lendir dehidrasi yang tebal di dalam rongga hidung dan nasofaring. ${ }^{12}$ Berdasarkan hasil penelitian di atas, kesehatan hidung di Balai Pelayanan Sosial Lanjut Usia Terlantar Senja Cerah Manado tergolong baik. 


\section{SIMPULAN}

Berdasarkan hasil penellitian pada lansia di BPSLUT Senja Cerah Manado, dapat disimpulkan bahwa sebagian besar lansia memiliki kesehatan hidung yang baik.

\section{SARAN}

Perlu dilakukan upaya promotif mengenai kesehatan hidung, mengingat kesehatan hidung sering disepelekan padahal sebenarnya kesehatan hidung berpengaruh pada kualitas hidup seseorang.

Perlu juga dilakukan pemeriksaan dan perawatan lanjutan bagi lansia dengan abnormalitas hidung ke dokter spesialis THT-KL.

Perlu dilakukan penelitian lanjut mengenai kesehatan hidung lansia dalam upaya mendeteksi lebih dini tentang masalah kesehatan hidung yang dapat terjadi.

\section{DAFTAR PUSTAKA}

1. Maulana HDJ. Promosi Kesehatan. Jakarta: EGC, 2009; p. 5.

2. Depkes RI. Analisis Lansia Indonesia 2017. Jakarta: Depkes RI, 2017.

3. Silverthorn UD. Fisiologi Manusia: Sebuah Pendekatan Terintegrasi (6th ed). Jakarta: EGC, 2013; p. 355.

4. Pitarini AP, Irawati N, Poerbonegoro NL, Wulandari D, Badarsono S. Perubahan kualitas hidup, eosinofil mukosa hidung, dan interleukin-5 serum pasien rinitis alergi pasca terapi. Jakarta: Fakultas Kedokteran Universitas Indonesia; 2015.

5. Nursanti, Ari. Ketepatan visual analog scale terhadap peak nasal inspiratory flow pada pengukuran sumbatan hidung penderita rinitis alergi persisten [Tesis]. Semarang: Fakultas Kedokteran Universitas Diponegoro; 2011.

6. Depkes RI. Indikator Indonesia Sehat Tahun 2010. Jakarta: Depkes RI, 2003.

7. Schlosser RJ. Epistaxis. NEJM. 2009;360(8): 784-9.

8. Bernstein J. Chronic rhinosinusitis with and without nasal polyposis. In: Sinusitis from Microbiology to Management. New York: Taylor and Francis, 2006; p. 37580.

9. Soepardi EA, Iskandar N, Bashiruddin J, Restuti RD. Buku Ajar Ilmu Kesehatan Telinga Hidung Tenggorok Kepala dan Leher (7th ed). Jakarta:Balai Penerbit: FKUI, 2012.

10. Pinto J, Jeswani S. Rhinitis in the geriatric population. Allergy Asthma Clin Immunol. 2010;6(1):10.

11. Maramis F, Palandeng $O$, Pelealu $O$. Kesehatan hidung pada siswa-siswi Sekolah Dasar Negeri 11 Manado [Skripsi]. Manado: Fakultas Kedokteran Universitas Sam Ratulangi; 2016.

12. Skoner DP. Allergic rhinitis: definition, epidemiology, pathophysiology, detection, and diagnosis. J Allergy Clin Immunol. 2001;108:S2-8

13. Busquets JM, Hwang PH. Nonpolypoid rhinosinusitis: classification, diagnosis and treatment. In: Bailey BJ, Johnson JT, Newlands SD, editors. Head \& Neck Surgery - Otolaryngology Vol 1 (4th ed). Philadelphia: Lippincott Williams \& Wilkins, 2006; p. 406-416. 